\title{
Study of Online Banking Solution for e-Governance initiatives: e- Procurement - A Scientific Knowledge
}

\author{
Shaikh Imtiyaj ${ }^{1}$, Er. Ratan kumar Agrawal ${ }^{2}$, Dr A K Hota ${ }^{3}$ \\ ${ }^{1}$ Senior Programmer Level 1, eProcurement Project, Ministry of Elect \& IT, NIC, Bhubaneswar, Odisha, India \\ ${ }^{2}$ Chief Engineer cum Chief Manager (Tech), eProcuremnet Cell, Govt. of Odisha, Bhubaneswar, Odisha, India \\ ${ }^{3}$ Scientist- Senior Technical Director, Ministry of Elect \& IT, Bhubaneswar, Odisha, India
}

\section{Introduction}

e-Governance aims to provide good governance to the public by using the Information and Communication Technology (ICT) for speedy, accurate, transparent and secured services. Information and Communication Technology is being increasingly used in daily life of a common man and it has become the nucleus part of providing the better governance services to the citizens of a country.Now a days, departments, business sectors and customers alike collect, store and transmit vast amount of information electronically and they want to believe that this information is secure. Hash functions are the most widespread among all cryptographic primitives and are currently used in multiple cryptographic schemes and security protocols. A Digital Signature Certificates (DSC) provides high level of security for online transactions. We study from various Government of Odisha departments like Works, water Resources, RD, H \& UD, SC \& ST Development, Agriculture Dept etc, 33 State PSUs and 106 urban local bodies. Central Government departments like Dept. of Posts, CRPF and Central Government PSUs like NALCO, Paradip Port Trust etc. This study focuses a humble effort towards nobel goal of developing the easy and secure way of online banking solutions for tendering process among departments and bidders in public domain.

In this research paper the online Tender fee and EMD process flow of funds is presented. The implementation of online tendering system is increasing day by day among different departments and PSUs for its superior level of security, strong authentication of Digital Signature Certificate, transparency and time stamping technique. E-Procurement provides the healthy competition among bidders and real time bidding over the internet yielding cost saving to the public exchequer which reduces the tender related crimes is certainly a significant achievement on the way to a better, cleaner, honest nation's development. To enhance the power of security and better implementation further research is in progress. This study focuses on different opportunities of G2B initiatives in India. The basic objective of research is to provide a model for better implementation of eGovernance application.

The use of Information Technology particularly web based internet applications to enhance the access to and delivery of government information and services to their citizens, public agencies, employees, business partners, financial institutions and government departments. The rapid growth of competition in the market and the consequent changes in economic conditions impose organizations and firms to implement new technologies to stay competitive. The Central, State Government, Judiciary, Autonomous Bodies, Boards \& Corporations, PSUs, Joint Ventures, Statutory Bodies, Commissions and Councils have invested in numerous initiatives throughout the length and breadth of the country aimed at extending the benefits of information revolution to rural and remote area. The Government envisions providing good governance by establishing a Committed, Accountable, Responsive, Inspiring, Nationalist, and Genuine Government - CARING Government. eProcurement is one of the best vehicles that are being gainfully used in reaching the goal of CARING governance

\section{e-Governance: Objective}

- Providing information speedily to all citizens

- Improving transparency

- Improving public services such as transportation, power, health, water, security and municipal services etc.

- Reduce Corruption

e-Governance development models :

The e-Governance Models are

- G2C : Government to Citizens

- G2B : Government to Business

- G2G : Government to Government 


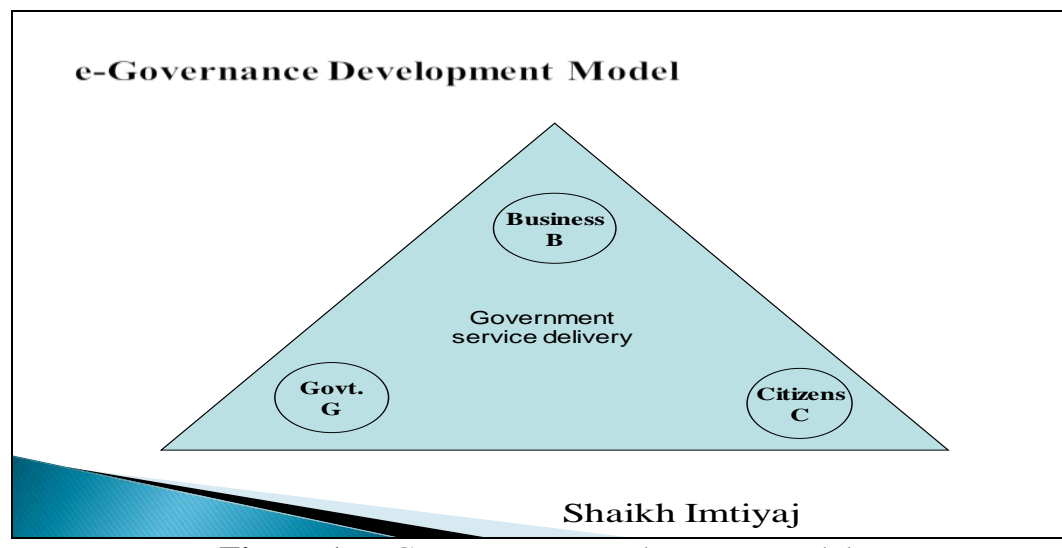

Figure 1: e-Governance Development Model

\section{II. e-Procurement}

A major Government to Business e-Governance initiative to bring transparency in public procurement process is e-Procurement.

e-Procurement, commonly known as Electronic procurement.

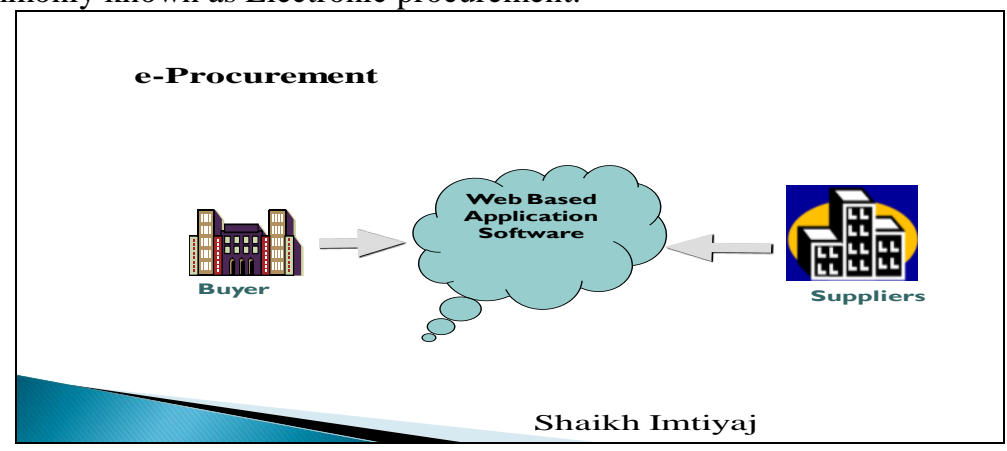

Figure 2: e-Procurement Cycle

e-Procurement is the business-to-business or business-to-consumer or business-to-Government purchase and sale of Supplies, Works and Services using the Internet. e-Procurement caters to the online tendering process from online tender creation to award of contract(AOC). Using e-Tendering the Departments can create the tender, publish the tender, receive bids, open the tenders, evaluate tenders and finally publish award of contract. Using e-Tendering, the bidders can search tenders, submit bids online and track the status of their bids. Timely and efficient delivery of e-Governance services is an important aspect. Indian IT-Act 2000 has mandated the usage of Digital Signature Certificate (DSC) for e-Procurement.

\section{Benefits of e-Procurement:}

For data encryption and security purposes, the Digital Signature Certificate is essential to operate in eProcurement.

\section{Benefits of e-Procurement}
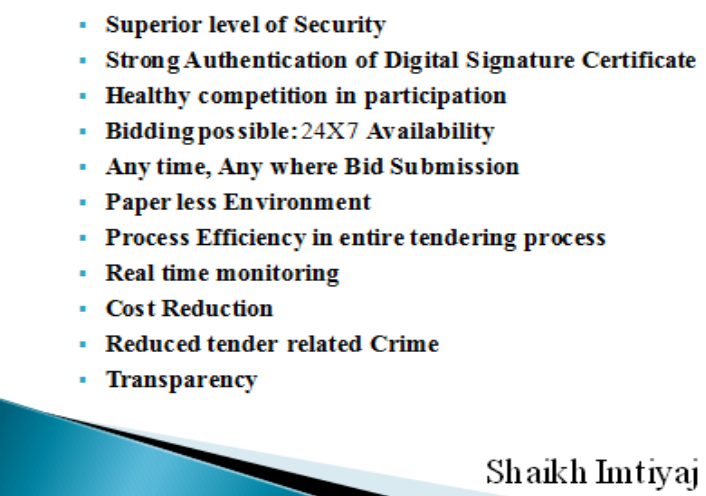

Shaikh Imtiyaj

Figure 3: Benefits of e-Procurement 
Roles in e-Procurement:

- Creater of the Tender: - The Tender will be created by the officer by using his/her Digital Signature Certificate, as per approved by the Department Nodal Officer.

- Publisher of the Tender:- He will be normally the Head of the Dept (HOD) of the concerned technical department and will be the responsible person for timely and accurately hosting of tender on the portal

- Opener of the Tender: - The tender will be decrypted and opened with the Digital Signature Certificates of each opener as identified during publishing the tender. Each opener will have to access one by one for bid opening. The Tender technical core committee members will be normally the openers of tender as decided by the Nodal Officer.

- Evaluator of the Tender: - The Evaluator is the person who will evaluate the tenders and upload the final decision of the Tender Evaluation Committee.

- Auditor: He will be given privileged access to audit tendering process.

Details of e-Procurement:

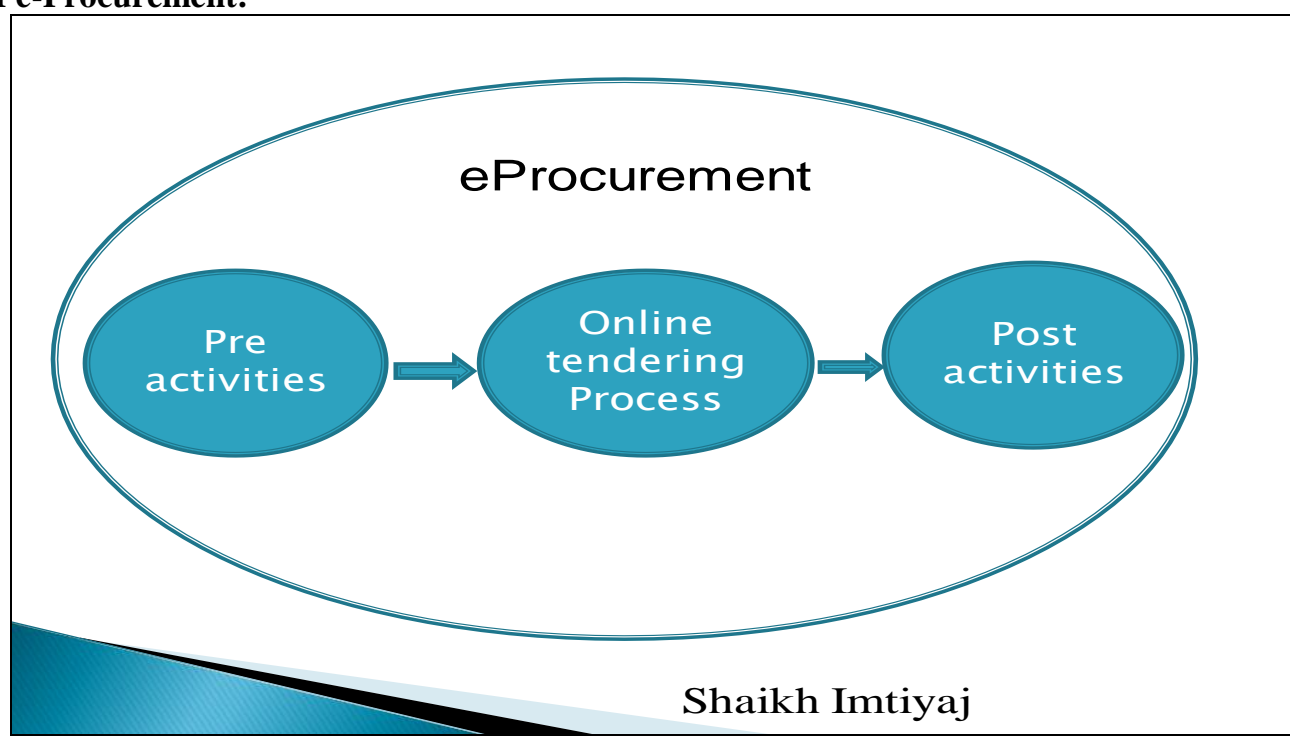

Figure 4: Knowledge of e-Procurement

e-Tendering Process :

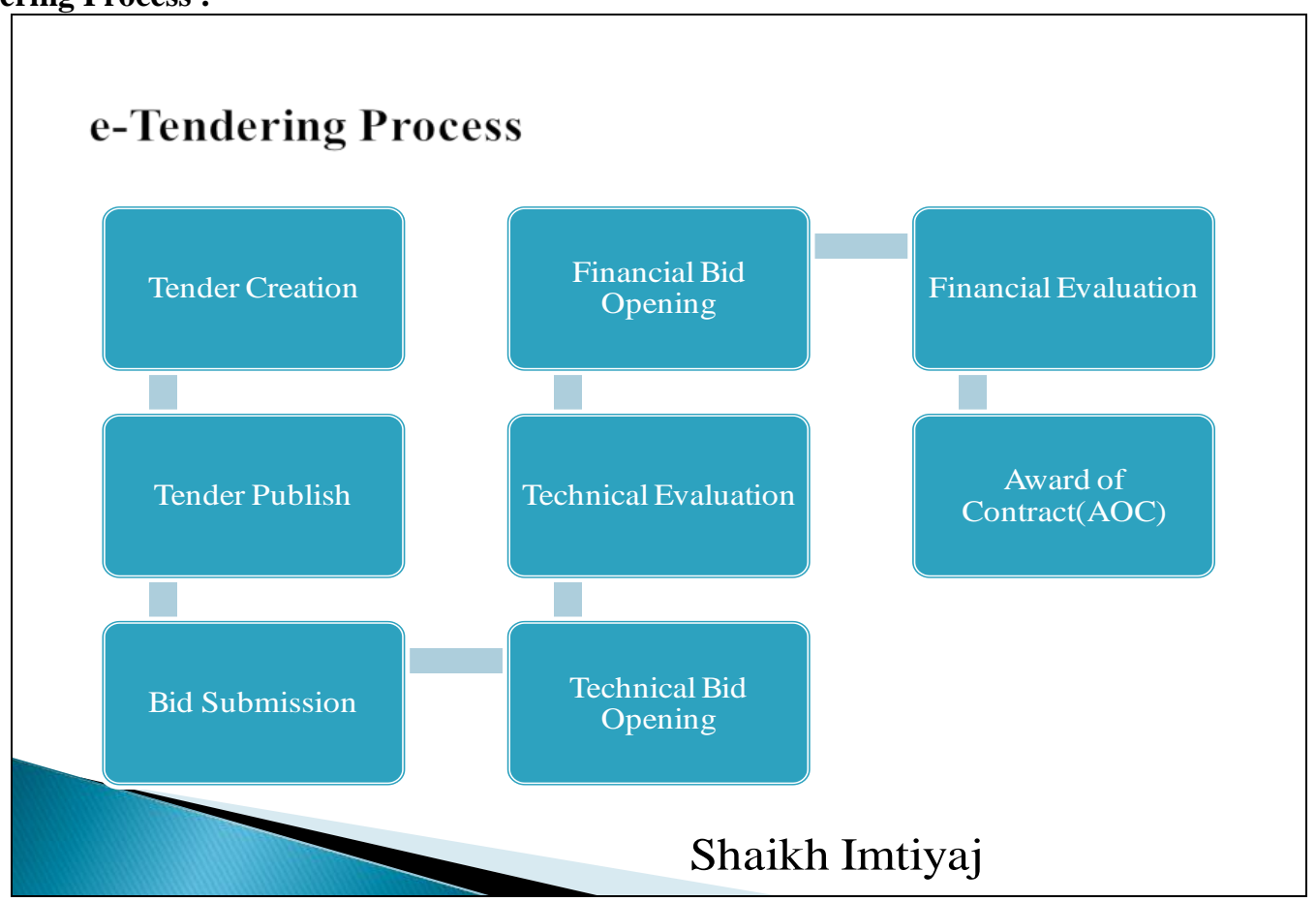

Figure 5: e-Tendering Process 
Bid Submission:

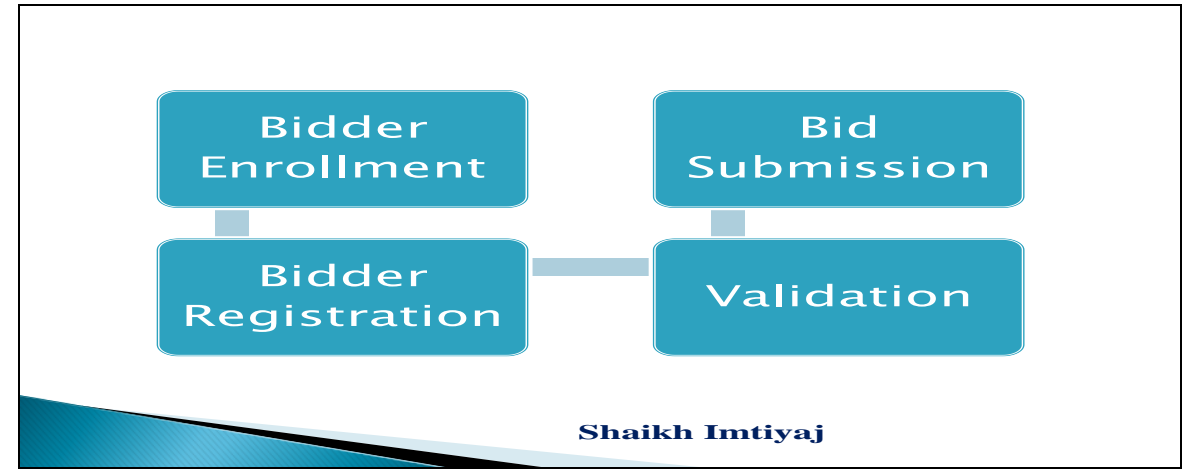

Figure 6: Bidder Process

- Bidder Enrollment: - Bidder submits valid login ID and follows the password policy to provide password. Bidder provides detail information to the portal.

- Bidder Registration: - Here bidder signing certificate is to be register in the Government of Odisha eProcurement portal.

- Validation: - According to Government of Odisha protocols, the bidder's uploaded documents will check and provides validation. The years of validation are 1 year or 3 years as concern department's rules and regulation.

Bid Submission:-

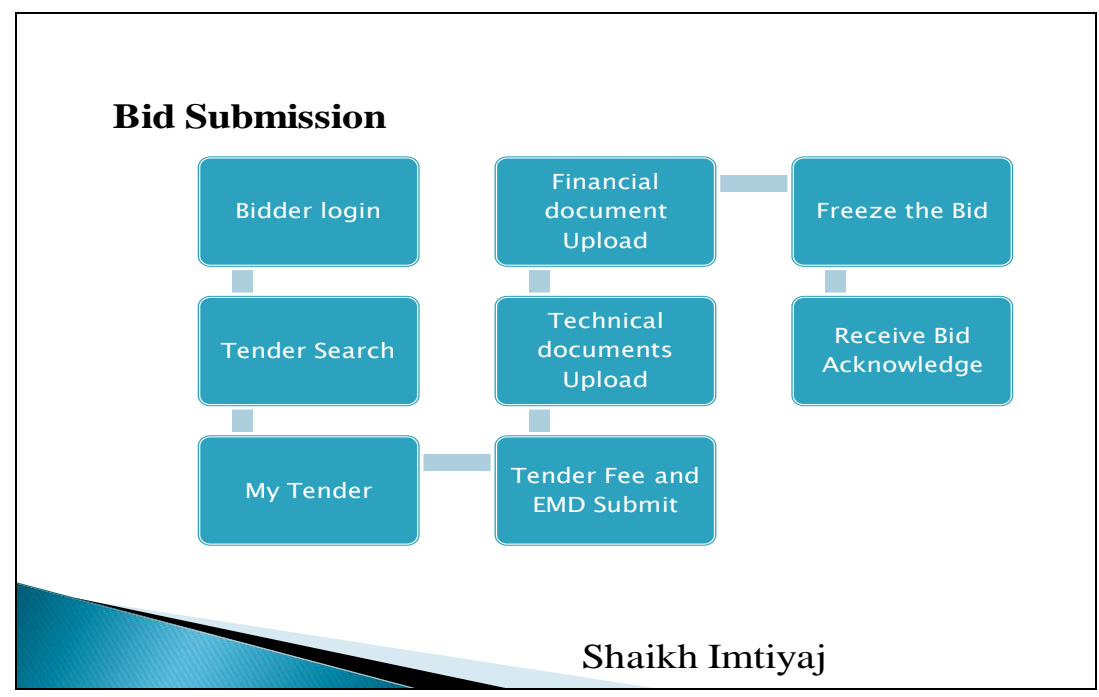

Figure 7: Bid Submission

III. Online Tender Fee And EMD Submission

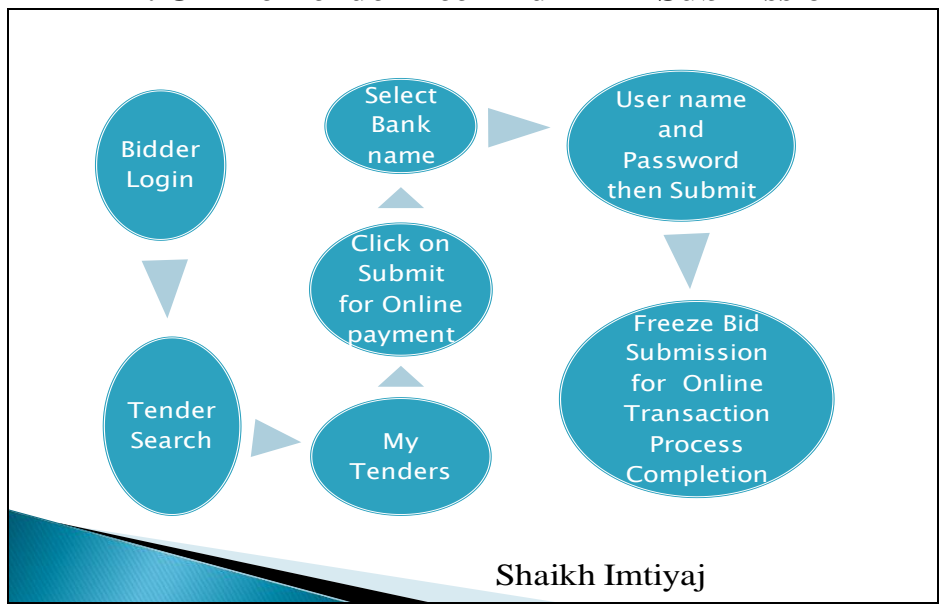

Figure 8: Online Tender Fee and EMD Submission 


\section{Process Flow Of Funds}

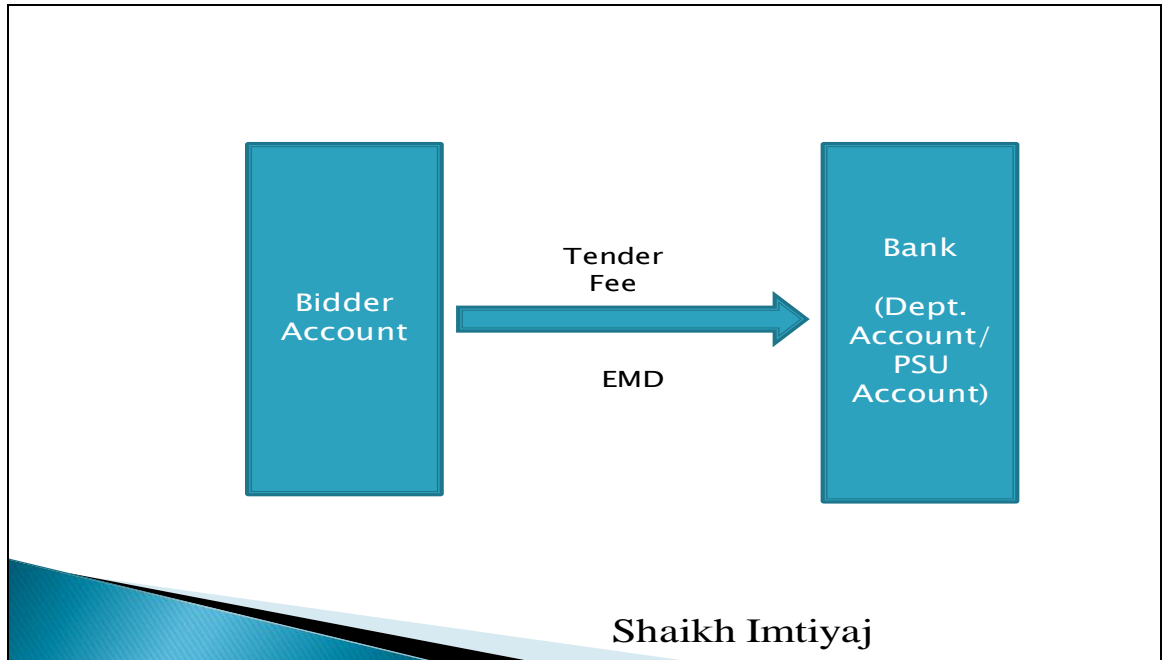

Figure 9: Process 1

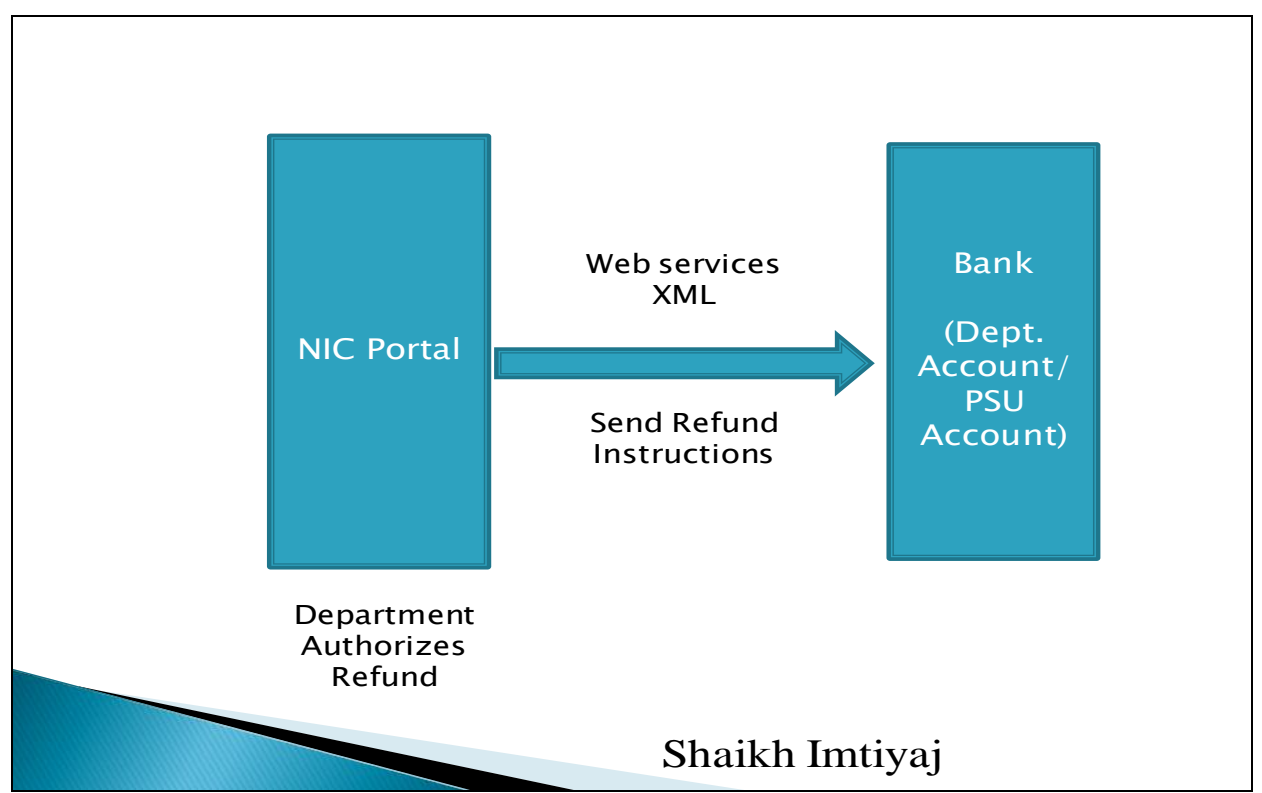

Figure 10: Process 2

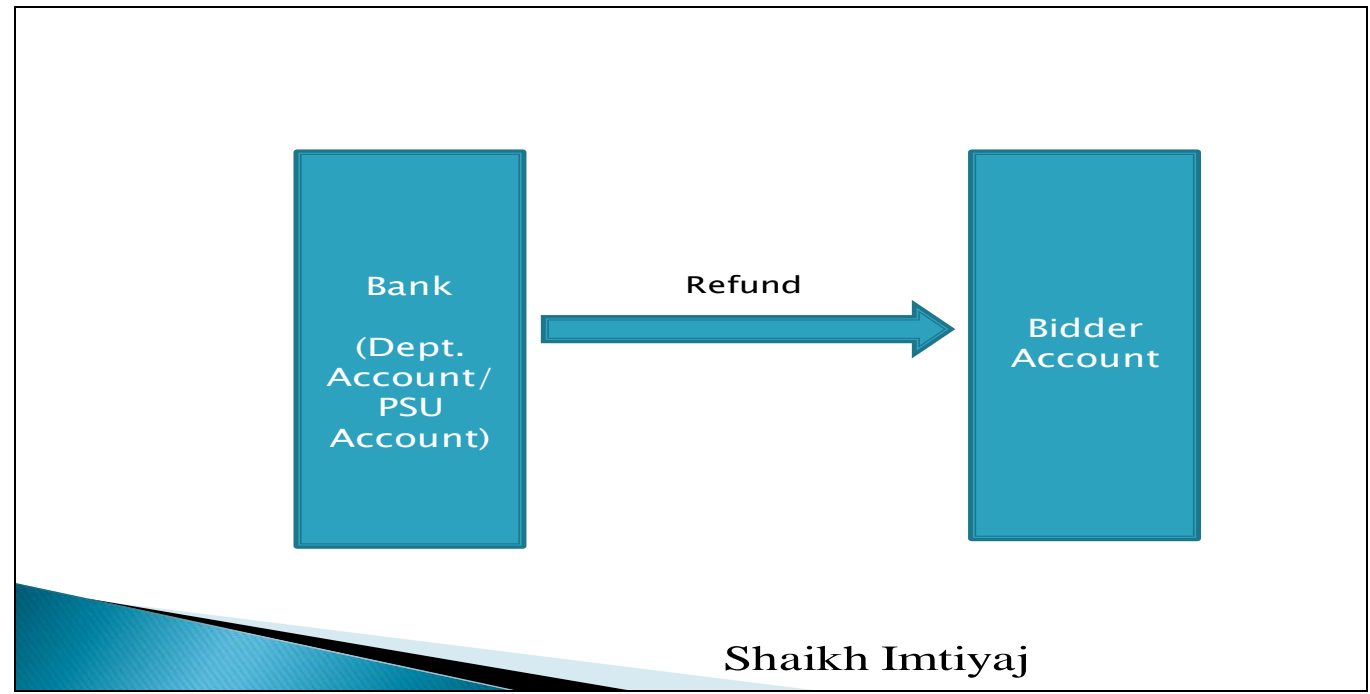

Figure 11: Process 3 


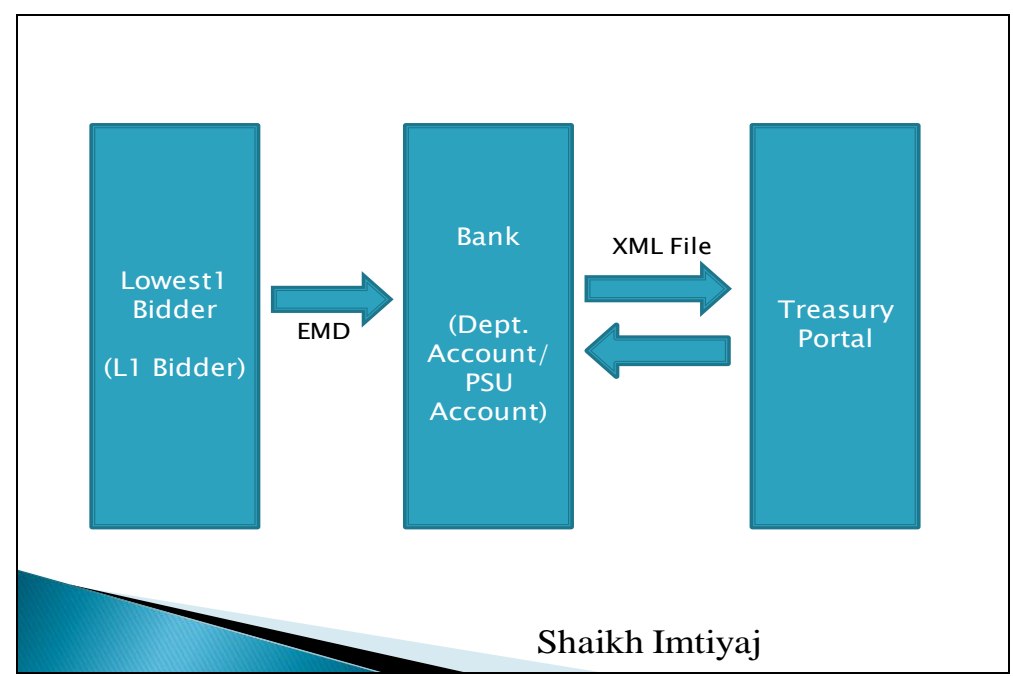

Figure 12: Process 4

\section{Risk In E-Procurement}

Digital Signature Certificates (DSC) can be presented electronically to prove the identity, to access information or services on the Internet or to sign certain documents digitally. DSC provides Authorization, Authentication, Privacy, Non repudiation and Integrity. IT Act 2000 in Government of India gives legal validity to electronic transactions that are digitally signed. A DSC provides high level of security for online transactions. You can use certificates to encrypt information such that only the intended recipient can read it. You can digitally sign information to provide assurance to the recipient that it has not been altered in transit, and enable verification that you actually sent the message.

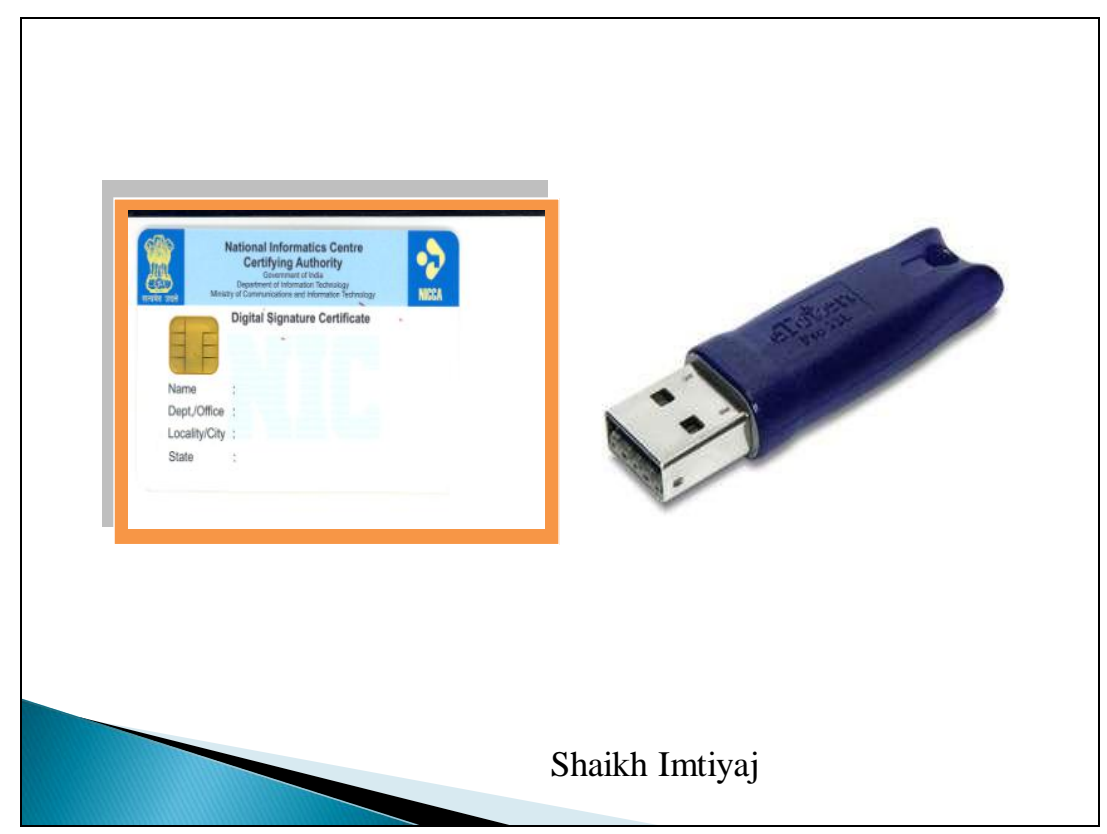

Figure 13: Digital Signature Certificates- Smart Card/ eToken

\section{Functions of DSC:}

1. Signing

2. Encryption/ Decryption

\section{Classes of Digital Signature Certificate (DSC):}

Depending upon requirement of assurance level and usage of DSC, the type of classes are follows:

Class-1 Certificate: provides minimum level of assurance.Intended for personal use. It does no strongly authenticate identity and is therefore not applicable for commercial use.

Class-2 Certificate: provides higher level of assurance confirming the details submitted in the DSC Request Form, including photograph and documentary proof in respect of at least one of the identification details. 
Class-3 Certificate: provides highest level of assurances, as verification process is very stringent and applicant has to present himself/herself before the CA.

Validity of Digital Signatures: One year validity \& two year validity. These are renewable.

\section{Algorithm}

DSC is based on MD5 algorithm from Cryptography. MD5 is Message Digest algorithm, which takes as input a message of arbitrary length and produces as output a 128-bit "message digest" of the input. MD5 is more secure than MD4.

\section{Conclusion And Future Work}

In this research paper the online Tender fee and EMD process flow of funds is presented. The implementation of online tendering system is increasing day by day among different departments and PSUs for its superior level of security, strong authentication of Digital Signature Certificate, transparency and time stamping technique. E-Procurement provides the healthy competition among bidders and real time bidding over the internet yielding cost saving to the public exchequer which reduces the tender related crimes is certainly a significant achievement on the way to a better, cleaner, honest nation's development. To enhance the power of security and better implementation further research is in progress. This study focuses on different opportunities of G2B initiatives in India. The basic objective of research is to provide a model for better implementation of eGovernance application.

\section{References}

[1]. Shaikh Imtiyaj, Er. Govinda Chandra Mangual, Dr. A K Hota "Study of e-Governance initiatives: e-Procurement a Business Reform Process for Odisha's Development”, IOSR Journal of Computer Engineering(IOSR-JCE) e-ISSN:2278-0661,p-ISSN:22788727,Volume 18,Issue 6,Ver. 1(Nov-Dec. 2016), PP 44-53

[2]. Shaikh Imtiyaj, Er Govinda Chandra Mangual, "An Indepth Understanding of e-Governance initiatives: e-Procurement -A Great Success in Odisha”, IOSR Journal of Computer Engineering(IOSR-JCE) e-ISSN:2278-0661,p-ISSN:2278-8727,Volume 18,Issue 4,Ver. V(Jul-Aug. 2016), PP 144-147

[3]. Shaikh Imtiyaj, N.R Biswal, T.P Ray, Dr A.K Hota, “An Indepth Understanding of e-Procurement : A Case Study Approach", IOSR Journal of Computer Engineering(IOSR-JCE) e-ISSN:2278-0661,p-ISSN:2278-8727,Volume 17,Issue 6,Ver. V(Nov-Dec. 2015), PP 20-24

[4]. Shaikh Imtiyaj, N.R Biswal, T.P Ray, Dr A.K Hota , "Digital Signature Certificate: A blessing for e-Governance Application in Human Development", International Journal of Advanced Research in Science, Engineering and Technology,Vol. 2, Issue 1, pp 350-355,January 2015

[5]. William S.," Cryptography and Network Security, Principles and Practice”, Prentice Hall of India, 2005.

[6]. Dhiren R. Patel ,'Information Security Theory and Practice", 2008 Edition

[7]. Atul Kahate, "Cryptography and Network Security", Second Edition

[8]. Cryptography Engineering: Design Principles and Practical Applications by Niels Ferguson, Bruce Schneier, Tadayoshi Kohno

[9]. www.eprocure.gov.in/eprocure/app, last visited $28^{\text {th }}$ Mar 2017

[10]. https://tendersodisha.gov.in/nicgep/app , last visited $28^{\text {th }}$ Mar 2017

[11]. "Digital Signature," available at: http:// http://nicca.nic.in , last visited $28^{\text {th }}$ Mar 2017

[12]. " "e-Governance," available at http:/ india.gov.in, last visited $28^{\text {th }}$ Mar 2017

[13]. "e-Procurement", available at http:/demoeproc.nic.in , last visited $28^{\text {th }}$ Mar 2017

[14]. http://www.odisha.gov.in/portal/ViewDetails.asp, last visited $28^{\text {th }}$ Mar 2017 